\title{
Adenovirus-Mediated Gene Transfer of Viral Interleukin-10 Inhibits the Immune Response to Both Alloantigen and Adenoviral Antigen
}

\author{
LIHUI QIN, ${ }^{1,2}$ YAOZHONG DING, ${ }^{1,2}$ DOMINIQUE R. PAHUD, ${ }^{1}$ NICOLE D. ROBSON, ${ }^{2}$ \\ ABRAHAM SHAKED, ${ }^{3}$ and JONATHAN S. BROMBERG ${ }^{1,2}$
}

\begin{abstract}
Although adenoviral vectors are attractive for gene transfer, their effectiveness is limited by host antiviral immune responses. In this study, we determined if host antiallograft and antiviral immunity could be diminished with an adenoviral vector encoding the immunosuppressive cytokine viral interleukin-10 (vIL-10). AdSV40vIL-10, a vIL-10-expressing adenoviral vector with an SV40 promoter, induced significant prolongation of murine cardiac allograft survival to $32.2 \pm 1.7$ days compared to $14.2 \pm 1.0$ days for controls $(p<$ 0.01). This effect was specific for vIL-10 encoding vector and could be inhibited by anti-vIL-10 monoclonal antibody (mAb). In vivo administration of adenovirus facilitated the generation of adenovirus-specific cytotoxic T lymphocytes (CTL), whereas treatment with AdSV40vIL-10 prevented CTL priming and generation of virus-specific immunity. AdSV40vIL-10 also induced extended expression of a $\beta$-galactosidase reporter from a co-injected LacZ-encoding adenoviral vector. These results demonstrate that adenovirus-mediated gene transfer and expression of vIL-10 prolong allograft survival and inhibit the immune response to adenoviral antigens, thereby improving the persistence of the vector and extending transgene expression. The efficacy of adenoviral vectors can be improved by incorporating immunosuppressive genes into the vector.
\end{abstract}

\section{OVERVIEW SUMMARY}

Adenoviral vectors are efficient for in vivo delivery of genes to a wide variety of tissue types, whereas the duration of expression is limited by the potent adenovirus-specific immune response directed to the infected cell. In this study, we demonstrate that adenovirus-mediated gene transfer and expression of viral interleukin-10 (vIL-10) not only prolongs murine cardiac allograft survival, but also inhibits the immune response toward adenoviral antigens, and thereby improves the persistence of the vector and extends transgene expression. These findings could be used to design a new generation of adenoviral vector that expresses both an immunosuppressive cytokine gene and another gene of interest. This strategy should have general application in many gene therapy settings other than transplantation. Nonetheless, although the efficacy of adenoviral vectors can be improved by incorporating immunosuppressive genes into the vector, there are also nonimmune mechanisms serving to limit vector gene expression.

\section{INTRODUCTION}

NTERLEUKIN-10 (IL-10) WAS ORIGINALLY DESCRIBED as cytokine synthesis inhibitory factor (Moore et al., 1990) and is able to regulate negatively a variety of immune responses. $\mathbb{L}-10$ is produced by macrophages and $\mathrm{TH} 2$ cells and inhibits the synthesis of cytokines by TH1 cells (de Waal Malefyt et al., 1991a; Taga and Tosato, 1992; Del et al., 1993), particularly interferon- $\gamma$ (IFN$\gamma$ ). IL-10 strongly downregulates class II major histocompatibility complex (MHC) expression on monocytes (de Waal Malefyt et al., 1991b), which is particularly important for antigen presentation. IL-10 also inhibits antigen-presenting cell (APC) functions (Ding et al., 1992, 1993; Enk et al., 1993); and the production of monokines (Fiorentino et al., 1991; Ralph et al., 1992; Cassatella et al., 1993; Scott 1993; Tripp et al., 1993), such as IL-8 (Cassatella et al., 1993), tumor necrosis factor- $\alpha$ (TNF- $\alpha$ ) (Ralph et al., 1992), and IL-12 (Tripp et al., 1993), an initiation cytokine for TH1 cell differentiation and cell-mediated immunity (Scott, 1993). IL-10 also has growth factor activities for a variety of cell types (Go et al., 1990; Chen and Zlotnik, 1991;

Departments of ${ }^{1}$ Surgery and ${ }^{2}$ Microbiology and Immunology, University of Michigan, Ann Arbor, MI 48109.

${ }^{3}$ Department of Surgery, University of Pennsylvania, Philadelphia, PA 19104. 
Thompson et al., 1991; Rousset 1992). Viral IL-10, a product encoded by the Epstein-Barr virus (EBV) BCRF 1 open reading frame, is homologous to both murine and human $\mathrm{LL}-10$, especially in the coding region of the mature protein sequence (Hsu et al., 1990; Moore et al., 1990; Vieira et al., 1991). Viral IL-10 shares many biological properties with murine and human $\mathrm{L}-10$, including cytokine synthesis inhibitory factor activity and downregulation of class II MHC expression on monocytes (Hsu et al., 1990; de Waal Malefyt et al., 1991b; Vieira et al., 1991). Viral IL-10, however, does not possess the $T$ cell co-stimulatory activities of authentic cellular IL-10 (MacNeil et al., 1990; de Waal Malefyt et al., 1991b), which makes vIL-10 potentially a more potent immunosuppressant.

Gene transfer and gene therapy for transplantation, which augment the production of immunosuppressive cytokines within the allograft, may markedly impair effective antigen presentation, reduce or eliminate immunogenicity, and prevent rejection or prolong graft survival while avoiding the systemic toxicity of conventional immunosuppression. Previous studies from our laboratory have shown that a variety of plasmid and viral (retrovirus, herpesvirus, adenovirus) vectors can successfully transfer and express exogenous genes in cardiac allografts (Qin et al., 1995). In particular, a retroviral vector encoding vIL-10 induced local immunosuppression and significantly prolonged allograft survival. Prolongation of graft survival was associated with specific inhibition of donor-specific cytotoxic T lymphocytes (CTL) and $\mathrm{IL}$-2-producing helper $\mathrm{T}$ lymphocytes, and inhibition of lymphocytic infiltration into the graft (Qin et al., 1996). The problem remains that although allograft survival is prolonged, it is not indefinite and tolerance has not been achieved. This is likely due to the fact that gene transfer is inefficient and expression is low and transient (Qin et al., 1995). Gains in allograft survival, therefore, require improvements in gene transfer and expression so that the immunosuppressive cytokines can be produced at higher amounts for longer periods of time. However, the use of retroviral vectors is restricted by their relatively low titer, low transfection efficiency, requirement for target cell replication, and the potential for malignant transformation of the target (Gordon and Anderson, 1994). In this study, we investigated the feasibility of using an adenoviral vector for improved transgene expression.

Adenoviral vectors are efficient for in vivo delivery of genes to a wide variety of tissue types and do not require target cell replication (Trapnell and Gorziglia, 1994; Bramson et al., 1995). Adenoviral vectors can accept exogenous DNA up to $7.5 \mathrm{~kb}$ in size and be easily produced in high titer (Trapnell and Gorziglia, 1994; Bramson et al., 1995). The major disadvantage of adenoviral vectors is that the duration of expression is limited by the potent adenovirus-specific immune response directed to the infected cell (Yang et al., 1994a,b; Dai et al., 1995). In this study, we also investigated whether gene transfer of vIL-10 could inhibit the host immune response against the adenoviral vector.

\section{MATERIALS AND METHODS}

\section{Mice}

CBA/J $\left(\mathbf{H}-2^{\mathrm{k}}\right)$ and $\mathrm{C} 57 \mathrm{BL} / 6 \mathrm{~J}\left(\mathrm{H}-2^{\mathrm{b}}\right)$ female mice $(8-10$ weeks of age) were purchased from The Jackson Laboratory
(Bar Habor, ME). Timed pregnant C57BL/6 were purchased from Harlan-Sprague-Dawley, Inc. (Indianapolis, IN).

\section{Adenoviral vectors}

All vectors are E1 deleted. AdHCMV $\beta$-gal encoding $\beta$ galactosidase $(\beta-\mathrm{Gal})$ under the control of the human cytomegalovirus (CMV) immediate early promoter, and AdSV40vIL-10 encoding vIL-10 under the control of SV40 early promoter were produced as previously described (Csete et al., 1994). Ad5, a control wild-type adenoviral vector without inserts or deletions, was provided by Dr. M. Imperiale (University of Michigan Medical Center). AdHCMVhAP encoding human alkaline phosphatase under the control of the human cytomegalovirus (HCMV) promoter, was obtained from vector core of UMMC. All vectors were adjusted to $1 \times 10^{10} \mathrm{pfu} / \mathrm{ml}$.

\section{Antibodies and cell lines}

The JES3-19F1.1 rat anti-human IL-10 (Bacchetta et al., 1994) hybridoma was purchased from the ATCC (Rockville, $\mathrm{MD}$ ); the 12-15 rat anti-murine CD2 hybridoma (Altevogt $e t$ al., 1989) was a gift of Dr. P. Altevogt. These two hybridomas were grown in culture and purified over protein G columns (Pharmacia-LKB, Piscataway, NJ). The L929 mouse fibroblast cell line (H-2k) (Ruff and Gifford, 1981) was purchased from the ATCC.

\section{Cardiac transplantation}

The heterotopic, nonvascularized cardiac transplantation model was used (Qin et al., 1995, 1996). Donor neonatal C57BL/6 mice were sacrificed and whole hearts were removed and placed in the subcutaneous position of the ear pinnae of $\mathrm{CBA} / \mathrm{J}$ or $\mathrm{C} 57 \mathrm{BL} / 6$ recipients. One $\times 10^{8}$ pfu of adenoviral vector in $10 \mu \mathrm{l}$ was directly injected into the graft at the time of transplantation and/or 10 days after transplantation. JES3$19 \mathrm{~F} 1.1 \mathrm{mAb}$ was injected intravenously at $100 \mu \mathrm{g}$ every other day for six doses. 12-15 mAb was injected intravenously at 100 $\mu \mathrm{g}$ on the day of transplantation (day 0 ) and 1 day after transplantation (day 1). mAbs were in $0.5-\mathrm{ml}$ volumes in phosphatebuffered saline (PBS). Survival of cardiac allografts was followed with EKG monitoring (Polygraph 78 Series with preamp and filters, Grass Instruments, Quincy, MA) every other day. Cessation of cardiac electrical activity was the determinant of rejection. There were at least 4 mice per group. Statistical comparison was performed with Student's $t$ test.

\section{CTL assay}

The CTL assay was performed as described (Yang et al., 1994a; DeMatteo et al., 1995) and modified as follows. $\mathrm{C} 57 \mathrm{BL} / 6$ to $\mathrm{CBA} / \mathrm{J}$ transplantation was performed as described above and graft-infiltrating lymphocytes (of $\mathrm{CBA} / \mathrm{J}$ recipient origin) were isolated 10 days after transplantation, plated at $1 \times$ $10^{6}$ cells per well in 24-well plates, and co-cultured with $4 \times$ $10^{6}, 2,000 \mathrm{rad}, \gamma$-irradiated CBA/J splenocytes in the presence of $15 \% 2 \mathrm{~m} M \alpha$-methyl mannoside-treated concanavalin A (ConA) supernatant [from 3-day ConA- $(5 \mu \mathrm{g} / \mathrm{ml})$ stimulated mouse spleens $\left(2 \times 10^{6}\right.$ cells $\left.\left./ \mathrm{ml}\right)\right]$. Naive CBA $/ \mathrm{J}$ mice were injected intravenously with $1 \times 10^{8} \mathrm{pfu}$ of adenoviral vector and splenic lymphocytes were isolated at 7 and 21 days after in- 
jection and plated at $5 \times 10^{6}$ cells per well in 24-well plates. All cultures were stimulated with Ad5 or AdHCMV $\beta$-gal at a multiplicity of infection (moi) of 10 for 5 days. Adenovirusspecific cytotoxic activity was assessed in a $4-\mathrm{hr},{ }^{51} \mathrm{Cr}$ release assay with Ad5 or AdHCMV $\beta$-gal-infected L929 as target, which was infected with Ad5 or AdHCMV $\beta$-gal at an moi of 501 day prior to assay.

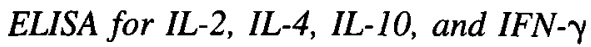

CTL culture supernatants were harvested after 3 days, and two-antibody capture enzyme-linked immunosorbent assays (ELISAs) for IL-2, IL-4, IL-10, and IFN- $y$ were performed as recommended by the manufacture (Pharmingen, San Diego, CA). Ninety-six well flat-bottomed plates were coated with 50 $\mu \mathrm{l}$ of anti-cytokine capture monoclonal antibodies (mAbs) at 2 $\mu \mathrm{g} / \mathrm{ml}$ in $0.1 M \mathrm{NaHCO}_{3}$ overnight at $4^{\circ} \mathrm{C}$. Plates were washed with $0.05 \%$ Tween-20 in PBS, blocked with $200 \mu \mathrm{l}$ of $3 \%$ bovine serum albumin (BSA) in PBS for $2 \mathrm{hr}$ at room temperature, washed, standards and culture supernatants added, and incubated overnight at $4^{\circ} \mathrm{C}$. Plates were again washed, incubated with $100 \mu$ l of biotinylated anti-cytokine-detecting mAbs at $1 \mu \mathrm{g} / \mathrm{ml}$ for $45 \mathrm{~min}$ at room temperature, washed, $100 \mu \mathrm{l}$ of a 1:1,000 dilution of peroxidase-conjugated streptavidin (Kirkegaard \& Perry, Gaithersburg, MD) added to each well, and incubated at room temperature for $30 \mathrm{~min}$. Plates were washed, $100 \mu \mathrm{l}$ of freshly prepared 2,2'-azino-bis 3-ethylbenzthiazoline-6-sulfonic acid (ABTS) solution (Kirkegaard \& Perry) added to each well, incubated at room temperature, and stopped by adding $100 \mu \mathrm{l}$ of $1 \%$ SDS. Plate O.D.s were measured at $405 \mathrm{~mm}$. Purified recombinant cytokines (Pharmingen) were used as standards.

\section{$X-G a l$ staining}

C57BL/6 syngeneic transplantation was performed as described above and the grafts were injected with $5 \times 10^{7}$ pfu of AdHCM $\beta$-gal in combination with $5 \times 10^{7}$ pfu of either Ad5 or AdSV40vIL-10. The ears with transplanted hearts were harvested at various time points after transplantation, quick-frozen, embedded in O.C.T. (Miles Scientific, Naperville, IL), sectioned at $10 \mu \mathrm{m}$, collected onto gelatin-coated glass slides, fixed at room temperature in $0.25 \%$ glutaraldehyde in PBS for 30 $\mathrm{min}$, rinsed three times in PBS for a total of $30 \mathrm{~min}$, and incubated at $37^{\circ} \mathrm{C}$ overnight in $0.5 \mathrm{mg} / \mathrm{ml} 5$-bromo-4-chloro-3-indolyl- $\beta$-D-galactopyranoside (X-Gal) solution containing $5 \mathrm{~m} M$ potassium ferrocyanide, $5 \mathrm{mM}$ potassium ferricyanide, $2 \mathrm{mM}$ $\mathrm{MgCl}_{2}, 1 \mathrm{~m} M$ spermidine, $0.02 \%$ Nonidet $\mathrm{P}-40$, and $0.01 \%$ sodium deoxycholate in PBS. After staining, the sections were fixed with $4 \%$ formaldehyde and counterstained with eosin (Qin et al., 1996).

\section{RESULTS}

\section{Adenoviral vector vIL-10 gene transfer prolongs allograft survival}

Allografts injected with AdSV40vIL-10 at $1 \times 10^{8} \mathrm{pfu} / \mathrm{graft}$ at the time of transplantation (day 0 ) showed mild prolongation of graft survival from $14.2 \pm 1.0$ days to $18.4 \pm 1.2$ days (Fig.
1), although this did not reach statistical significance $(p>$ $0.01)$. This dose of adenoviral vector is not toxic nor does it cause cytopathic effects to the graft because syngeneic grafts injected with the same dose of this vector had indefinite survival up to 150 days (now shown). Reducing the dose of adenoviral vector to $1 \times 10^{7}$ or $1 \times 10^{6} \mathrm{pfu} / \mathrm{graft}$ produced no prolongation of graft survival (Fig. 1). This effect on graft survival is far less than that provided by administering $5 \times 10^{3} \mathrm{pfu} / \mathrm{graft}$ of a retroviral vector encoding vIL-10, which prolonged graft survival to $39.4 \pm 2.5$ days (Qin et al., 1996). This difference is likely due to the different expression profiles of genes transferred by these two different vectors as a result of differences in promoters and immunogenicity (Qin et al., 1995). For example, using the LacZ reporter gene, we previously demonstrated that the adenoviral vector AdHCMV $\beta$-gal transferred intense expression of $\beta$-Gal for only a short period of time to $\mathrm{CBA} / \mathrm{J}$ syngeneic cardiac grafts. The highest expression was observed 5 days after gene transfer, with up to $30 \%$ of cells stained by X-Gal. Thereafter, the number of positive cells declined rapidly. Only $5 \%$ of cells showed positive staining 10 days after gene transfer, and none of the cells were positive by 15 days after gene transfer (Qin et al., 1995). In contrast, when the retroviral vector CRIP-MFG-LacZ was administered, $\beta$-Gal expression could be observed even 30 days after gene transfer, although fewer than 1\% cells were positive (Qin et al., 1995). These results suggest that prolonged allograft survival requires expression of even low levels of vIL-10 for an extended period of time. Therefore, we administered a second dose of the adenoviral vector 10 days after transplantation, a time at which the graft was still viable and the anti-adenoviral neutralizing anti-
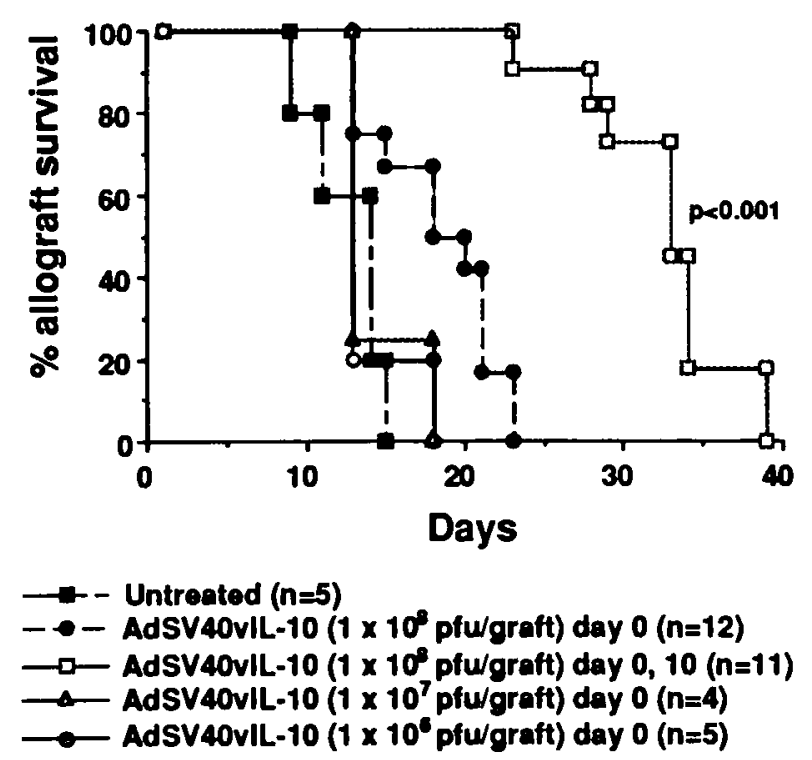

FIG. 1. AdSV40vIL-10 prolongs allograft survival. C57BL/6 hearts were transplanted to CBA/J recipients. AdSV40vIL-10 in $10 \mu$ l was directly injected into the allograft at the doses indicated at the time of transplantation (day 0 ) and/or 10 days later (day 10). Survival of cardiac allografts was followed by EKG monitoring every other day. AdSV40vIL-10 significantly prolonged allograft survival only when the vector was administered for two doses both on the day of transplantation and 10 days later. 
body response was not yet measurable (not shown), but expression of the first adenoviral vector inoculum was reduced but not completely eliminated. This treatment significantly prolonged graft survival to $32.2 \pm 1.7$ days $(p<0.001$ ) (Fig. 1). Additional injections of AdSV40vIL-10 were not performed, because significant titers of adenovirus-specific neutralizing antibodies developed 21 days after a single injection of the adenoviral vector (not shown), and this was expected to limit the efficacy of further repeated injections of AdSV40vIL-10. These results with two administrations of AdSV40vIL-10 are similar to those with a single administration of retroviral vIL-10 gene delivery and demonstrate that adenovirus-mediated gene transfer of vIL-10 significantly prolongs allograft survival only when the vector is administered for two doses, both on the day of transplantation and 10 days later. This also implies that expression from the first viral inoculum was limited by nonimmune mechanisms, because the second inoculum was able to extend graft survival, which would not have been expected if there was a significant anti-adenoviral immune response.

\section{Prolongation of allograft survival is due to $v I L-10$ expression}

The specificity of vIl-10 gene transfer was determined. Wild-type adenovirus have unique ways of escaping from host immature surveillance by producing an E3 region protein that down-regulates MHC class 1 expression on the cell surface and thus reduces lysis of the infected cells by CTL (Wold and Gooding, 1991). Even though the recombinant adenoviral vectors lack E1 protein and the transcription of E3 protein is at a very low level, it is still possible that by injecting two sequential
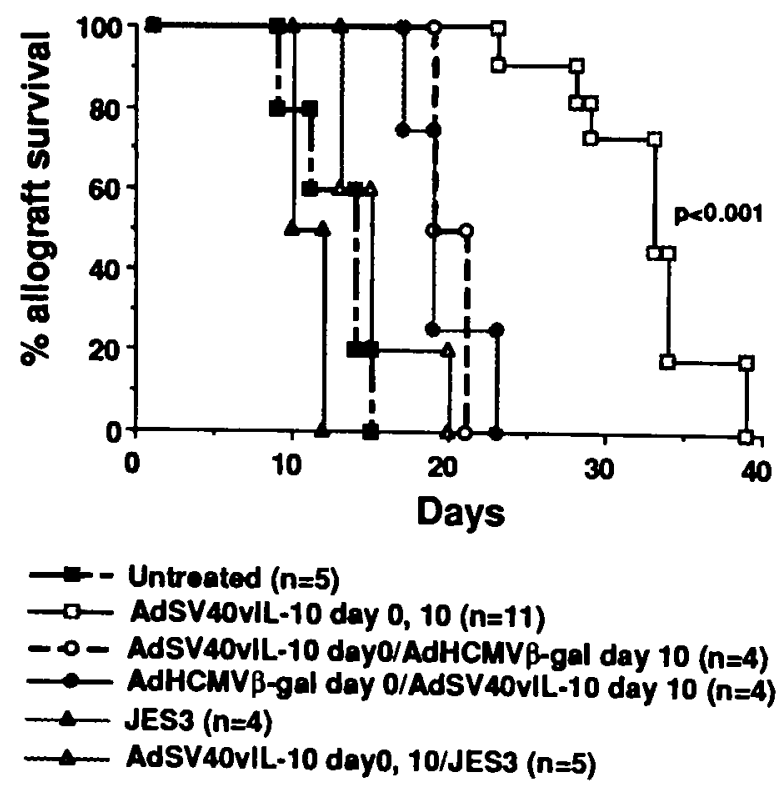

FIG. 2. The prolongation of allograft survival by two sequential doses of AdSV40vIL-10 is due to vIL-10 expression. AdSV40vIL-10 and/or AdHCMV $\beta$-gal were directly injected into the allograft at $1 \times 10^{8}$ pfu per graft at the time of transplantation (day 0 ) and 10 days later (day 10 ). The vIL-10-neutralizing antibody JES3-19F1.1 was injected intravenously at $100 \mu \mathrm{g}$ every other day for six doses. doses of adenoviral vectors, the expression of $\mathrm{E} 3$ protein, rather than vIL-10, could inhibit the immune response against alloantigens. To test this possibility, AdSV40vIL-10 was administered at time of transplantation (day 0 ) and AdHCMV $\beta$-gal 10 days after transplantation (day 10), or AdHCMV $\beta$-gal was administered day 0 and AdSV40vIL-10 on day 10. Both of these treatments produced no significant survival advantage compared to a single dose of AdSV40vIL-10 (Fig. 2). Thus, adenoviral vectors alone did not prolong graft survival, suggesting that vIL-10 rather than $\mathrm{E} 3$ gene delivery was required for immunosuppression. The specificity of vIL-10 was further confirmed by administering anti-vIL-10 mAb (JES3-19F1.1, a neutralizing antibody that cross-reacts with human $\mathrm{IL}-10$ and vIL-10 but not $\mathrm{mIL}-10$ ) to the transplant recipients after vIL10 gene transfer. This treatment abrogated the effect of sequential administration of AdSV40vIL-10 and reduced graft survival to $15.2 \pm 1.3$ days (Fig. 2). These results demonstrate that AdSV40vIL-10 gene transfer specifically prolongs allograft survival through expression of vIL-10 protein over an extended period of time.

\section{vIL-10 gene transfer prevents adenovirus-specific CTL priming in graft infiltrating cells}

Previous results (Qin et al., 1996) show that vIL-10 gene transfer prolongs allograft survival and is associated with the inhibition of allospecific CTL responses. MHC class I-restricted CD8 ${ }^{+}$ $T$ cells also play a central role in host antiviral immune responses by either direct CTL-mediated lysis of infected cells or secretion of cytokines, such as IFN- $\gamma$, which influence viral gene expression (Doherty et al., 1992; Yang et al., 1994b). Therefore, the effect of vIL-10 on adenovirus-specific CTL activity was next investigated. Graft-infiltrating cells were obtained 10 days after transplantation and gene transfer, restimulated in vitro with Ad5infected syngeneic spleen cells for 5 days, and assayed for adenovirus-specific CTL activity by a 4-hr ${ }^{51} \mathrm{Cr}$ release assay using Ad5-infected L929 $\left(\mathrm{H}-2^{\mathrm{k}}\right)$ targets. The results demonstrate that in vivo treatment with AdHCMV $\beta$-gal facilitated the generation of adenovirus-specific CTL, whereas treatment of AdSV40vIL10 prevented CTL priming (Fig. 3). This experiment was performed three times with similar results.

\section{vIL-10 gene transfer inhibits systemic adenovirus- specific immunity}

The data in Fig. 3 show that vIL-10 gene transfer inhibits adenovirus-specific CTL generation. A potential problem with the experiment is that two vectors with different promoters were used. Thus, the minor differences in vector structure might cause some difference in CTL generation even though both vectors were generated from adenovirus type 5 with $\mathrm{E} 1$ region deletion, and were propagated and prepared in the same way. As an alternative way of evaluating this issue, mice were injected intravenously with the combination of adenoviral vector Ad5 plus AdHCMV $\beta$-gal, AdHCMVhAP plus AdHCMV $\beta$-gal, or AdSV40vIL-10 plus AdHCMV $\beta$-gal. Anti-vIL-10 mAb JES3$19 F 1.1$ was also administered to animals that received AdSV40vIL-10 plus AdHCMV $\beta$-gal to confirm the specificity of vIL-10. Splenic lymphocytes were harvested 7 and 21 days after injection, restimulated in vitro with AdHCMV $\beta$-gal-infected stimulators, and assayed for adenovirus-specific CTL ac- 


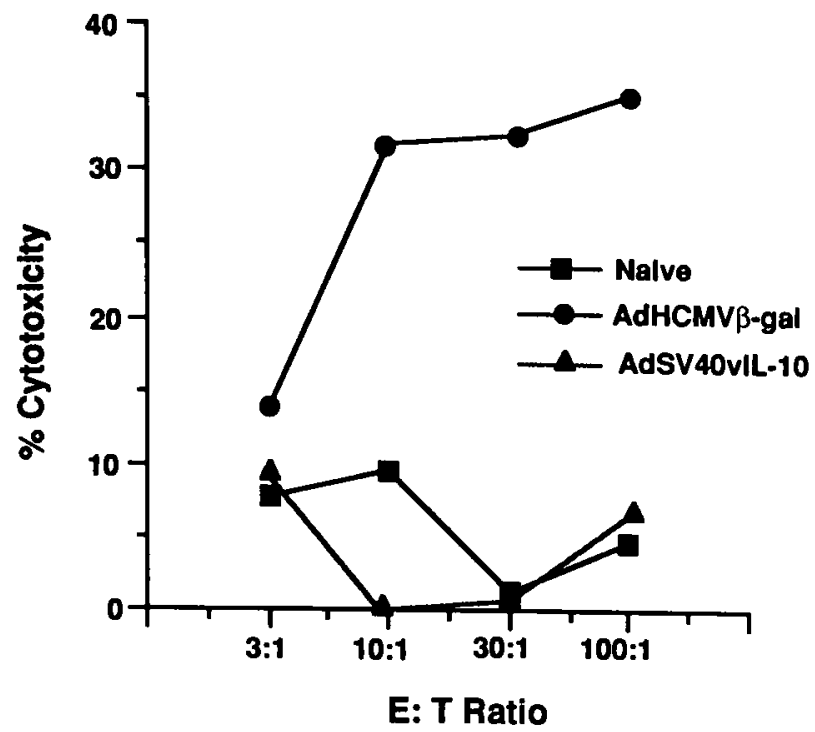

FIG. 3. Viral IL-10 gene transfer inhibits adenovirus-specific CTL priming in graft-infiltrating lymphocytes. CBA/J recipients were transplanted with $\mathrm{C} 57 \mathrm{BL} / 6$ hearts injected with $1 \times$ $10^{8} \mathrm{pfu}$ of the indicated adenoviral vectors. Graft infiltrating cells were harvested 10 days after transplantation, restimulated in culture with syngeneic (CBA/J) splenocytes infected with Ad5, and assayed for CTL activity using Ad5 infected L929 as targets. At least 10 allografts were used for each group for each experiment. The experiment was repeated three times with similar results.

tivity with AdHCMV $\beta$-gal-infected targets. The results show that vIL-10 gene transfer inhibited the generation of adenoviral-specific CTL, and anti-vIL-10 administration prevented this inhibition (Fig. 4). The inhibition of CTL by vIL-10 is also associated with a significant decrease in IFN- $\gamma$ production in the culture supernatant (Fig. 5), whereas IL-2, IL-4, and IL-10 production remain at low levels and unchanged (not shown). Despite inhibiting adenovirus-specific CTL activity, vIL-10 gene transfer did not alter adenovirus-specific proliferative $T$ cell responses in vitro (not shown).

\section{vIL-10 gene transfer results in extended adenovirus- mediated reporter gene expression}

Because vIL-10 gene transfer and expression prolonged allograft survival and inhibited the CTL and TH1 response to adenoviral vector, it was important to determine if gene transfer would also prolong expression of a reporter gene delivered by the adenovirus. C57BL/6 syngeneic transplantation was performed into C57BL/6 recipients and the grafts were injected with AdHCMV $\beta$-gal in combination with either Ad5 or AdSV40vIL-10. The ears with transplanted hearts were harvested 5,10 , and 20 days later, and $\beta$-Gal expression was determined by X-Gal staining. Both groups revealed intense $\beta$ Gal expression 5 days after gene transfer (Fig. 6A,B), with more than $30 \%$ of cells stained by X-Gal. By day 10 , the $\beta$-Gal expression in the Ad5/AdHCMV $\beta$-gal group was dramatically decreased, with less than $5 \%$ of the cells positive (Fig. $6 \mathrm{C}$ ), whereas $\beta$-Gal expression in the AdSV40vIL-10/AdHCMV $\beta$ gal group decreased more slowly, with $15 \%$ of the cells still positive (Fig. 6D). Twenty days after gene transfer, the Ad5/Ad-
HCMV $\beta$-gal group showed no $\beta$-Gal expression (Fig. $6 \mathrm{E}, \mathrm{G}$ ), whereas the AdSV40vIL-10/AdHCMV $\beta$-gal group maintained $\beta$-Gal expression in a significant number of cells (Fig. $6 \mathrm{~F}, \mathrm{H}$ ). Therefore, adenovirus-mediated gene transfer and expression of vIL-10, which inhibit the immune response to adenoviral antigens, are sufficient to improve the persistence of vector and transgene containing cells and result in substantially longer transgene expression.

\section{Inhibition of $T$ cell function by anti-CD2 mAb does not synergize with AdSV4OvIL-10 to prolong allograft survival}

The results demonstrate that prolongation of allograft survival requires continuous expression of vIL-10 for an extended period of time (Fig. 1). Because $T$ cells are the primary effectors mediating both allograft destruction and viral clearance (Yang et al., 1994a,b; Dai et al., 1995), inhibition of T cell activity by administration of other immunosuppressants may improve adenoviral vector persistence and allow longer vector function and transgene expression (Engelhardt et al., 1994; Dai et al., 1995; Dematteo et al., 1996). Other immunosuppressants may therefore synergize with AdSV40vIL-10 to prolong allograft survival. The anti-CD2 mAb 12-15 has previously been shown in our model to inhibit a wide variety of both $\mathrm{CD} 4^{+}$and $\mathrm{CD}^{+}{ }^{-}$-mediated cellular events (Chavin et al., 1994; Qin et al., 1994). We tested whether anti-CD2 mAb could synergize with AdSV40vIL-10 to prolong allograft survival by inhibiting multiple $T$ cell responses. AdSV40vIL-10 was injected into allografts on day 0 and $100 \mu \mathrm{g}$ of anti-CD2 mAb, a dose known to be optimal for inhibition of CD4 and CD8 T cell immunity, was injected intravenously into allograft recipients on day 0 and day 1 . The combination of AdSV40vIL-10 and anti$\mathrm{CD} 2 \mathrm{mAb}$ prolonged graft survival to $26.4 \pm 2.8$ days $(n=5$ ), which was not significantly different compared to anti-CD2 $\mathrm{mAb}$ alone (24.4 \pm 1.0 days) (Qin et al., 1994) and not as effective as two sequential doses of the adenoviral vector. This result suggests that despite dual immunosuppression by anti$\mathrm{CD} 2 \mathrm{mAb}$ and vIL-10 at the time of allografting, inhibition of $\mathrm{CD}^{+}$and $\mathrm{CD} 8^{+} \mathrm{T}$ cells and APC was not sufficient to prevent the attenuation or extinction of expression of the transferred vIL-10 gene from the single inoculum of viral vector. This result and the readministration results both imply that immune destruction of infected cells is not the sole mechanism of transgene extinction and that nonimmune phenomena limit transferred gene expression by affecting promoter function or disposition of episomal DNA (Tsui et al., 1995; Guidotti et al., 1996; Yao et al., 1996; Worgall et al., 1977). We also have further evidence in our model that despite the lack of reporter gene expression, vector DNA persists (unpublished results), which agrees with the findings of others (Dwarki et al., 1995; Yao et al., 1996).

\section{DISCUSSION}

Adenoviral vectors are attractive for gene transfer because of their broad host range, capacity for large DNA inserts, and high titers. However, the in vivo application of first-generation recombinant adenoviruses (with E1 deletion) is limited by host 


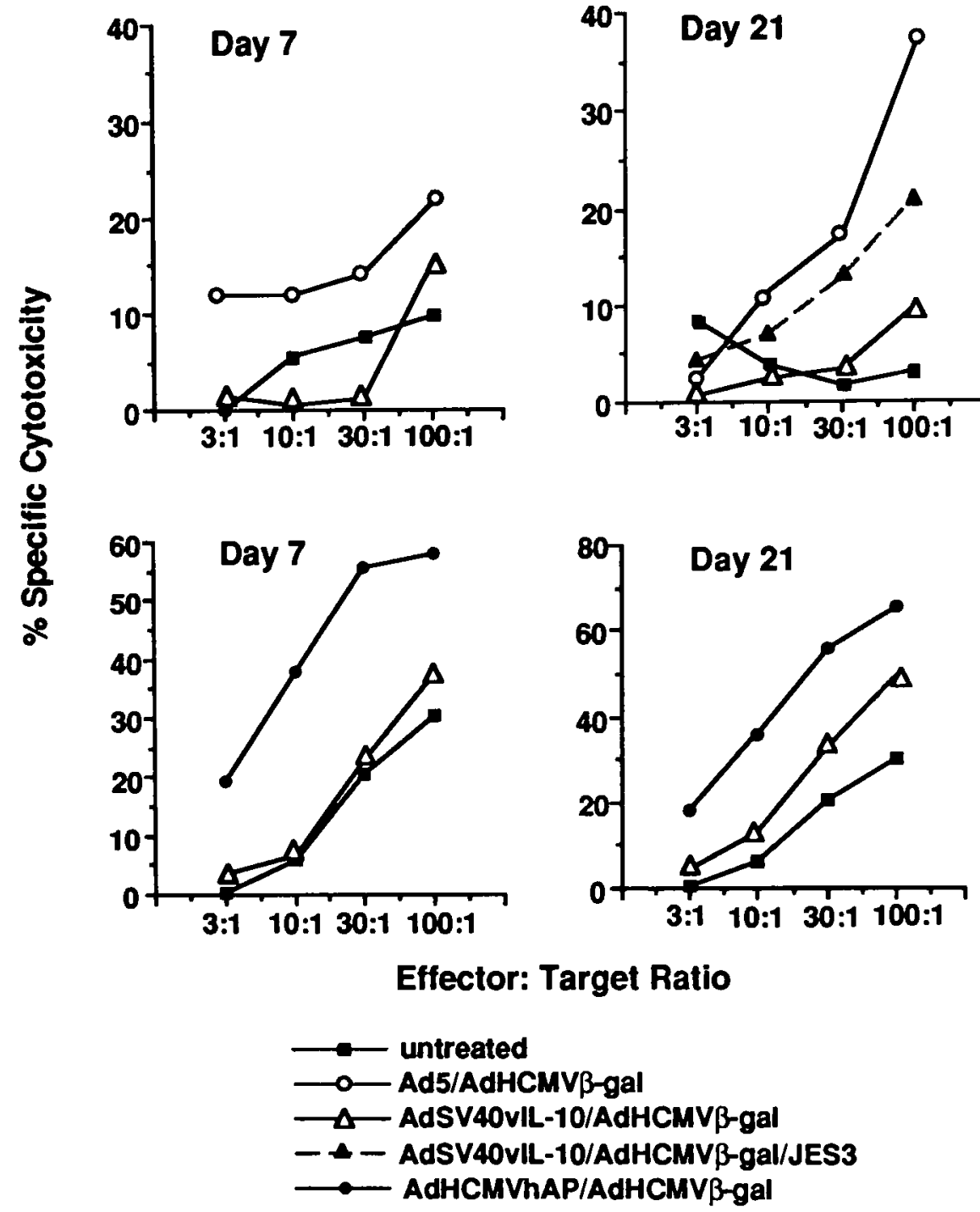

FIG. 4. Viral IL-10 gene transfer inhibits adenovirus-specific CTL generation in splenic lymphocytes. CBA/J mice were injected intravenously with $2 \times 10^{8}$ pfu of the indicated combination of adenoviral vectors. The vIL-10-neutralizing antibody JES319F1.1 was injected intravenously at $100 \mu \mathrm{g}$ every other day for six doses. Seven and 21 days later, splenic lymphocytes were isolated, restimulated in culture with AdHCMV $\beta$-gal, and assayed for CTL activity using AdHCMV $\beta$-gal-infected L929 as targets. Four animals were used for each group at each time point. The experiment was repeated three times with similar results.

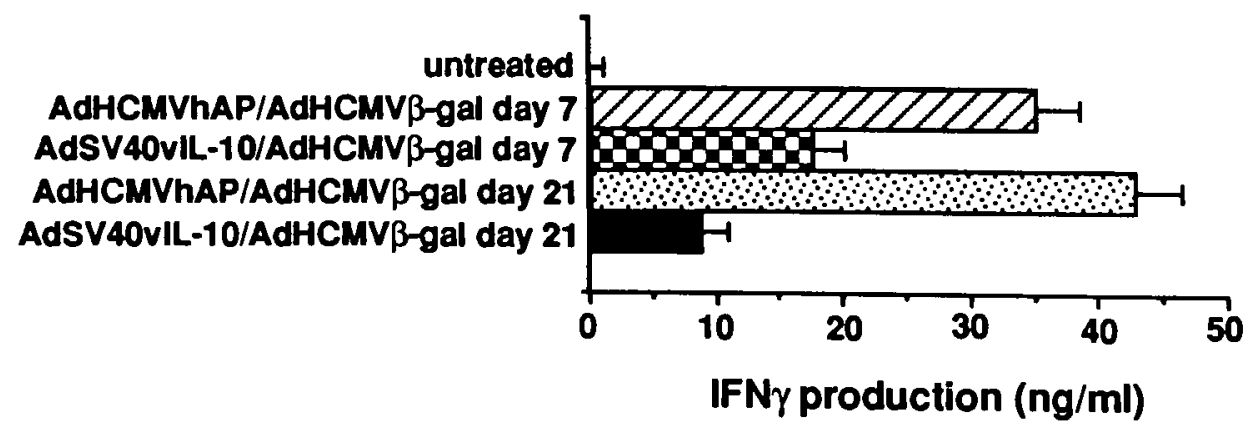

FIG. 5. Viral IL-10 gene transter inhibits adenovirus-induced $1 F N-\gamma$ production. Culture supernatants were harvested after 3 days, and two-antibody capture ELISA for IFN- $\gamma$ was performed. 


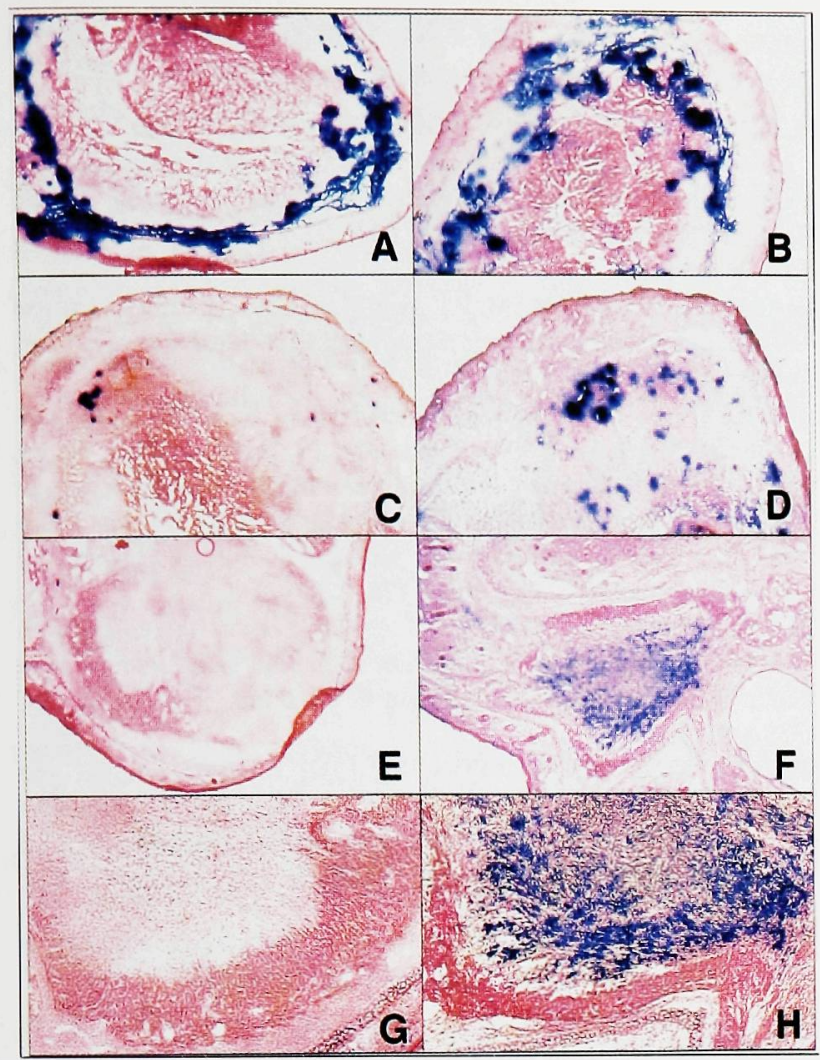

FIG. 6. Viral IL-10 gene transfer induces extended reporter gene expression. C57BL/6 syngeneic transplants were performed and the grafts were injected with $5 \times 10^{7}$ pfu of Ad5/AdHCMV $\beta$-gal (A, C, E, and G) or AdSV40vIL-10/AdHCMV $\beta$-gal (B, D, F and $\mathrm{H}$ ). The ears with transplanted hearts were harvested $5(\mathrm{~A}, \mathrm{~B}), 10(\mathrm{C}, \mathrm{D})$, and $20(\mathrm{E}, \mathrm{F}, \mathrm{G}$, and $\mathrm{H})$ days later for $\mathrm{X}$-Gal staining. Original magnification: $100 \times$ $(\mathrm{A}-\mathrm{F})$ and $250 \times(\mathrm{G}$ and $\mathrm{H})$. There are at least three grafts for each group at each time point.

antiviral immune responses (Yang et al., 1994a,b; Dai et al., 1995). Recombinant adenoviral vectors express low levels of viral genes that stimulate cellular responses, which involve $\mathrm{CD}^{+}$CTL, CD4 ${ }^{+}$TH1 cells, IFN- $\gamma$, and IL-2 (Doherty et al., 1992; Yang et al., 1994b) and lead to destructive inflammation and transient transgene expression. Several approaches have been taken to circumvent the immune response to adenoviral vectors. One approach is to engineer a less immunogenic vector by further deletion of the E2 region from the adenoviral genome (Engelhardt et al., 1994; Yang et al., 1994c). However, as further deletions are made in the adenoviral genome, the virus becomes more difficult to propagate and obtain in high titer (Engelhardt et al., 1994).

Another approach is to suppress the immune system of the host by using immunosuppressive drugs such as cyclophosphamide (Dai et al., 1995) and cyclosporine A (Engelhardt et al., 1994; Dai et al., 1995), or depleting CD4 ${ }^{+}$T cell (Dematteo et al., 1996). Unfortunately, the systemic administration of these immunosuppressants will affect systemic immune function and result in a number of complications, such as infection and malignancy, and other undesirable side effects, which make it less attractive for clinical application.
The third approach is to induce unresponsiveness to adenoviral antigens by intrathymic inoculation (DeMatteo et al., 1995). The involuted thymus of adult humans make this approach not feasible for human gene therapy.

A fourth approach is to induce local immunosuppression by generating adenoviral vectors that constitutively express immunomodulatory molecules, such as the $19 \mathrm{~K}$ glycoprotein (gp 19K) found in the adenoviral E3 region (Lee et al., 1995), or the interleukin-1 receptor antagonist (IL-1Ra) (McCoy et al., 1995). However, expression of IL-1Ra is unable to prevent adenoviral vector-induced inflammation (McCoy et al., 1995).

IL-10 is a potent immunosuppressive cytokine that has a variety of negative effects on IFN- $\gamma$ production, $\mathrm{CD} 8^{+} \mathrm{CTL}$, and $\mathrm{CD} 4^{+} \mathrm{TH} 1$ cells activities, all of which have been shown to be important effectors for host antiviral immune responses (Doherty et al., 1992; Yang et al., 1994b). In addition, IL-10 shows antiinflammatory activity by inhibiting the production of proinflammatory cytokines, such as IL- $1 \beta$, IL-6, IL-8, TNF- $\alpha$ (de Waal Malefyt et al., 1991a; Fiorentino et al., 1991; Ding and Shevach, 1992), and up-regulating the human monocyte production of soluble TNF receptors and IL-1Ra (Cassatella et al., 1993). Therefore vIL-10 may be a more potent immunosuppressive molecule compared to IL-1Ra, which competes with IL- $1 \alpha$ and IL- $1 \beta$ for binding to the IL- 1 receptor (Cassatella et al., 1993), and gp 19K of adenovirus E3 region, which binds to class I antigens to block the transport of MHC class I to the cell surface (Wold and Gooding, 1991).

In this study, we tested the feasibility of using an adenoviral vector encoding vIL-10 to induce local immunosuppression within allografts to prolong allograft survival and suppress host antiadenoviral immune responses. The results demonstrate that adenovirus-mediated gene transfer and expression of vIL-10 may not prolongs murine cardiac allograft survival, but also inhibits the immune response toward adenoviral antigens, and thereby improves the persistence of the vector and extends transgene expression. These findings could be used to design a new adenoviral vector that express both an immunosuppressive cytokine gene and another gene of interest. Alternatively, two different vectors could be administered simultaneously. This strategy should have general applications in many gene therapy settings other than transplantation.

Previously, we demonstrated that a variety of plasmid and viral (retrovirus, herpesvirus, adenovirus) vectors successfully transferred and expressed exogenous genes in cardiac transplants (Qin et al., 1995). The duration and the distribution of transferred gene expression depended on vector characteristics (Qin et al., 1995). For retroviral vectors, expression was low but relatively prolonged. A retroviral vector encoding vIL-10 significantly prolonged allograft survival by inducing local immunosuppression, which was associated with specific inhibition of the recruitment and/or generation of donor-specific CTL and IL-2-producing helper T lymphocytes within the grafts, and inhibition of lymphocytic infiltration within the graft (Qin et al., 1996). In contrast, a single injection of vIL10 protein at the time of transplantation had no effect on allograft survival (Qin et al., 1996).

In this study, we demonstrated that a single administration of adenoviral vector encoding vIL-10, which presumably provided high-level vIL-10 protein expression for only a short 
period of time, was also not sufficient to prolong allograft survival (Fig. 1). Adenovirus-mediated gene transfer of vIL-10 significantly prolonged allograft survival only when the vector was administered for two doses, both on the day of transplantation and 10 days later (Fig. 1). Because cytokine proteins nornually have a very short half-life, high-level expression of vIL-10 for only a short period after transplantation would not be expected to be sufficient to inhibit allograft rejection. These results all suggest that prolonged expression of the gene product, which provides localized immunosuppressive effects within the graft, is needed for improved graft survival.

It is important to note that the immune response toward adenoviral antigens is probably just one of the mechanisms that lead to short-term transgene expression. Many experiments demonstrate that even by using less immunogenic E2deleted adenoviral vectors (Engelhardt et al., 1994; Yang et al., 1994c), immunosuppressants to inhibit the host immune system (Engelhardt et al., 1994; Dai et al., 1995; Dematteo et al., 1996), or immunodeficient mice (Dematteo et al., 1995) lacking $\mathrm{CD} 8^{+} \mathrm{T}$ cells (MHC class I-deficient mice), $\mathrm{CD}^{+} \mathrm{T}$ cells (MHC class II-deficient mice), or both $\mathrm{T}$ and B cells (SCID mice), transgene expression improved, but was not sustained at high levels. Likewise the results here show that despite inhibiting $T$ cell immune responses with vIL-10 or anti$\mathrm{CD} 2 \mathrm{mAb}$, transgene expression was still limited. The ability to readminister AdSV40vIL-10 and achieve prolonged graft survival also suggests nonimmune limitations to transgene expression. Others (Dwarki et al., 1995; Yao et al., 1996) have shown persistence of vector DNA despite the lack of transgene expression. Even using retroviral vectors, which incorporate into the genome and theoretically could result in permanent transgene expression, indefinite gene expression is only achieved in vitro but not in vivo (Scharfmann et al., 1991; Challita and Kohn, 1994; Rettinger et al., 1994), especially when strong viral promoters are used.

These results all suggest that nonimmune, noncytolytic mechanisms are significant determinants of transgene expression. Recent evidence suggests that cytokines produced by specific or nonspecific immune responses may limit gene expression by negatively regulating transcriptional activity, translational rates, or mRNA turnover from certain viral promoters or enhancers (Tsui et al., 1995; Guidotti et al., 1996; Yao et al., 1996; Worgall et al., 1997). In particular, these studies showed that promoter extinction, attenuation, or inactivation may occur without killing the virus-infected cells. Indeed, we have preliminary data suggesting that certain cytokines affect promoter expression from viral vectors (L.Q., J.S.B., unpublished data). Therefore, the study of promoter structure and an understanding of cytokine-transcription factor-promoter interactions will likely be required to improve these aspects of gene therapy.

\section{ACKNOWLEDGMENTS}

We thank Dr. M. Imperiale (UMMC) for providing adenoviral vector and helpful discussions, and Ms. K. Cherian (UMMC) for preparation of adenoviral vector.

\section{REFERENCES}

ALTEVOGT, P., KOHL, U., VON, H.P., LANG, E., and SCHIRRMACHER, V. (1989). Antibody 12-15 cross-reacts with mouse Fc gamma receptors and CD2: Study of thymus expression, genetic polymorphism and biosynthesis of the $\mathrm{CD} 2$ protein. Eur. J. Immunol. 19, 341-346.

BRAMSON, J.L., GRAHAM, F.L., and GAULDIE, J. (1995). The use of adenoviral vectors for gene therapy and gene transfer in vivo. Curr. Opin. Biotechnol. 6, 590-595.

CASSATELLA, M.A., MEDA, L., BONORA, S., CESKA, M., and CONSTANTIN, G. (1993). Interleukin 10 (IL-10) inhibits the release of proinflammatory cytokines from human polymorphonuclear leukocytes. Evidence for an autocrine role of tumor necrosis factor and IL-1 beta in mediating the production of IL-8 triggered by lipopolysaccharide. J. Exp. Med. 178, 2207-2211.

CHALLITA, P.M., and KOHN, D.B. (1994). Lack of expression from a retroviral vector after transduction of murine hematopoietic stem cells is associated with methylation in vivo. Proc. Nat1. Acad. Sci. USA 91, 2567-2571.

CHAVIN, K.D., QIN, L., YON, R., LIN, J., YAGITA, H., and BROMBERG, J.S. (1994). Anti-CD2 monoclonal antibodies suppress cytotoxic lymphocyte activity by the generation of $\mathrm{T}_{\mathrm{H}} 2$ suppressor cells and receptor blockade. J. Immunol. 152, 3729-3739.

CHEN, W.F., and ZLOTNIK, A. (1991). IL-10: a novel cytotoxic T cell differentiation factor. J. Immunol. 147, 528-534.

CSETE, M.E., DRAZAN, K.E., BREE, M.V., and SHAKED, A. (1994). Adenovirus-mediated gene transfer in the transplant setting. Part I: Conditions for expression of transferred genes in cold preserved hepatocytes. Transplantation 57, 1502-1507.

DAI, Y., SCHWARZ, E.M., GU D., ZHANG, W.W., SARVETNICK, N., and VERMA, I.M. (1995). Cellular and humoral immune responses to adenoviral vectors containing factor IX gene: tolerization of factor IX and vector antigens allows for long-term expression. Proc. Natl. Acad. Sci. USA 92, 1401-1405.

DE WAAL MALEFYT, R., ABRAMS, J., BENNETT, B., FIGDOR, C.G., and DE VRIES, J.E. (1991a). Interleukin 10 (IL-10) inhibits cytokine synthesis by human monocytes: an autoregulatory role of IL-10 produced by monocytes. J. Exp. Med. 174, 1209-1220.

DE WAAL MALEFYT, R., HAANEN, J., SPITS, H., RONCARLOL, M.G., TE VELDE, A., FIGDOR, C., JOHNSON, C., KASTELEIN, R., YSSEL, H., and DE VRIES, J.E. (1991b). Interleukin 10 (IL-10) and viral IL-10 strongly reduce antigen-specific human $T$ cell proliferation by diminishing the antigen-presenting capacity of monocytes via downregulation of class $\Pi$ major histocompatibility complex expression. J. Exp. Med. 174, 915-924.

DEL, P.G., DE, C.M., ALMERIGOGNA, F., GIUDIZI, M.G., BIAGIOTTI, R., and ROMAGNANI, S. (1993). Human IL-10 is produced by both type 1 helper (TH1) and type 2 helper (Th2) T cell clones and inhibits their antigen-specific proliferation and cytokine production. J. Immunol. 150, 353-360.

DEMATTEO, R.P., RAPER, S.E., AHN, M., FISHER, K.J., BURKE, C., RADU, A., WIDERA, G., CLAYTOR, B.R., BARKER, C.F., and MARKMANN, J.F. (1995). Gene transfer to the thymus. A means of abrogating the immune response to recombinant adenovirus. Ann., Surgery 222, 229-242.

DEMATTEO, R.P., MARKMANN, J.F., KOZARSKY, K.F., BAKER, C.F., and RAPER, S.E. (1996). Prolongation of adenoviral transgene expression in mouse liver by T-lymphocyte subset depletion. Gene Ther. 3, 4-12.

DING, L., and SHEVACH, E.M. (1992). IL-10 inhibits mitogen-induced $\mathrm{T}$ cell proliferation by selectively inhibiting macrophage costimulatory function. J. Immunol. 148, 3133-3139. 
DING, L., LINSLEY, P.S., HUANG, L.Y., GERMAIN, R.N., and SHEVACH, E.M. (1993). IL-10 inhibits macrophage costimulatory activity by selectively inhibiting the up-regulation of $B 7$ expression. $J$ Immunol. 151, 1224-1234.

DOHERTY, P.C., ALLAN, W., and EICHELBERGER, M. (1992), Roles of $\alpha \beta$ and $\gamma \delta$ T cell subsets in viral immunity. Annu. Rev. Immunol. 10, 123-151.

DWARKI, V.J., BELLONI, P., NIJJAR, T., SMITH, J., COUTO, L., RABIER, M., CLIFT, S., BERNS, A., and COHEN, L.K. (1995). Gene therapy for hemophilia A: Production of therapeutic levels of human factor VIII in vivo in mice. Proc. Natl. Acad. Sci. USA 92, 1023-1027.

ENGELHARDT, J.F., YE, X., DORANZ, B., and WILSON, J.M. (1994). Ablation of E2a in recombinant adenoviruses improves transgene persistence and decreases inflammatory response in mouse liver. Proc. Natl. Acad. Sci. USA 91, 6196-6200.

ENK, A.H., ANGELONI, V.L., UDEY, M.C., and KATZ, S.I. (1993). Inhibition of Langerhans cell antigen-presenting function by IL-10. A role for IL-10 in induction of tolerance. J. Immunol. 151, 2390-2398.

FIORENTINO, D.F., ZLOTNIK, A., MOSMANN, T.R., HOWARD, M., and O'GARRA, A. (1991). IL-10 inhibits cytokine production of activated macrophages. J. Immunol. 147, 3815-3822.

GO, N.F., CASTLE, B.E., BARRETT, R., KASTELEIN, R., DANG, W., MOSMANN, T.R., MOORE, K.W., and HOWARD, M. (1990), Interleukin 10, a novel B cell stimulatory factor: unresponsiveness of X chromosome-linked immunodeficiency B cells. J. Exp. Med. $172,1625-1631$.

GORDON, E.M., and ANDERSON, W.F. (1994). Gene therapy using retroviral vectors. Curr. Opin. Biotechnol. 5, 611-616.

GUIDOTTI, L.G., ISHIKAWA, T., HOBBS, M.V., MATZKE, B. SCHREIBER, R., and CHISARI, F.V. (1996). Intercellular inactivation of the hepatitis $\mathrm{B}$ virus by cytotoxic $\mathrm{T}$ lymphocytes. Immunity 4, 25-36.

HSU, D.H., DE WAAL MALEFYT, R., FIORENTINO, D.F., DANG, M.N., VIEIRA, P., DEVRIES, J.E., SPITS, H., MOSMANN, T.R., and MOORE, K.W. (1990). Expression of interleukin-10 activity by Epstein-Barr virus protein BCRF1. Science 250, 830-832.

LEE, M.G., ABINA, M.A., HADDADA, H., and PERRICAUDET, M. (1995). The constitutive expression of the immunomodulatory gp19k protein in E1-, E3-adenoviral vectors strongly reduces the host cytotoxic $\mathrm{T}$ cell response against the vector. Gene Ther. 2 , 256-262.

MACNEIL, I.A., SUDA, T., MOORE, K.W., MOSMANN, T.R., and ZLOTNIK, A. (1990). IL-10, a novel growth cofactor for mature and immature T cells. J. Immunol. 145, 4167-4173.

MCCOY, R.D., DAVIDSON, B.L., ROESSLER, B.J., HUFFNAGLE, G.B., and SIMON, R.H. (1995). Expression of human interleukin1 receptor antagonist in mouse lung using a recombinant adenovirus: effects on vector-induced inflammation. Gene Ther. 2, $437-442$.

MOORE, K.W., VIEIRA, P., FIORENTINO, D.F., TROUNSTINE, M.L., KHAN, T.A., and MOSMANN, T.R. (1990). Homology of cytokine synthesis inhibitory factor (IL-10) to the Epstein-Barr virus gene BCRFI. Science 248, 1230-1234.

QIN, L., CHAVIN, K.D., LIN, J., YAGITA, H., and BROMBERG, J.S. (I994). Anti-CD2 receptor and anti-CD2 ligand (CD48) antibodies synergize to prolong allograft survival, J. Exp. Med. 179, 341-346.

QIN, L., CHAVIN, K.D., DING, Y., FAVARRO, J.P., WOODWARD, J.E., LIN, J., TAHARA, H., ROBBINS, P.D., SHAKED, A., HO, D.Y., SAPOLSKY, R.M., LOTZE, M.T., and BROMBERG, J.S. (1995). Multiple vectors effectively achieve gene transfer in a murine cardiac transplantation model: Immunosuppression with TGF- $\beta 1$ or vIL-10. Transplantation 59, 809-816.
QIN, L., CHAVIN, K.D., DING, Y., TAHARA, H., FAVARO, J.P., WOODWARD, J.E., SUZUKI, T., ROBBINS, P.D., LOTZE, M.T., and BROMBERG, J.S. (1996). Retrovirus-mediated transfer of viral interleukin-10 gene prolongs murine cardiac allograft survival. J. Immunol. 156, 2316-2323.

RALPH, P., NAKOINZ, I., SAMPSON, J.A., FONG, S., LOWE, D., MIN, H.Y., and LIN, L. (1992). IL-10, T lymphocyte inhibitor of human blood cell production of $\mathrm{IL}-1$ and tumor necrosis factor. $\mathrm{J}$. Immunol. 148, 808-814.

RETTINGER, S.D., KENNEDY, S.C., WU, X., SAYLORS, R.L., HAFENRICHTER, D.G., FLYE, M.W., and PONDER, K.P. (1994). Liver-directed gene therapy: Quantitative evaluation of promoter elements by using in vivo retroviral transduction. Proc. Natl. Acad. Sci. USA 91, 1460-1464.

ROUSSET, F., GARCLA, E., DEFRANCE, T., PERONNE, C., VEZZIO, N., HSU, D.H., KASTELEIN, R., MOORE, K.W., and BANCHEREAY, J. (1992). Interleukin 10 is a potent growth and differentiation factor for activated human B lymphocytes. Proc. Natl. Acad. Sci. USA 89, 1890-1893.

RUFF, M.R., and GIFFORD, G.E. (1981). Rabbit tumor necrosis factor: Mechanism of action. Infect. Immun. 31, 380-386.

SCOTT, P. (1993). IL-12: Initiation cytokine for cell-mediated immunity. Science 260, 496-497.

SCHARFMANN, R., AXELROD, J.H., and VERMA, I.M. (1991). Long-term in vivo expression of retrovirus-mediated gene transfer in mouse fibroblast implants. Proc. Natl. Acad. Sci. USA 89, $4626-4630$.

TAGA, K., and TOSATO, G. (1992). L-10 inhibits human T cell proliferation and IL-2 production. J. Immunol. 148, 1143-1148.

THOMPSON, S.L., DHAR, V., BOND, M.W., MOSMANN, T.R., MOORE, K.W., and RENNICK, D.M. (1991). Interleukin 10: A novel stimulatory factor for mast cells and their progenitors. J. Exp. Med. 173, 507-510.

TRAPNELL, B.C., and GORZIGLIA, M. (1994). Gene therapy using adenoviral vectors. Curr. Opin. Biotechnol. 5, 617-625.

TRIPP, C.S., WOLF, S.F., and UNANUE, E.R. (1993). Interleukin 12 and tumor necrosis factor alpha are costimulators of interferon gamma production by natural killer cells in severe combined immunodeficiency mice with listeriosis, and interleukin 10 is a physiologic antagonist. Proc. Natl. Acad. Sci. USA 90, 3725-3729.

TSUI, L.V., GUIDOTTI, L.G., ISHIKAWA, T., and CHISARI, F.V. (1995). Posttranscriptional clerance of hepatitis B virus RNA by cytotoxic T lymphocyte-activated hepatocytes. Proc. Natl. Acad. Sci. USA 92, 12398-12402.

WORGALL, S., WOLFF, G., FALCK-PEDERSEN, E., and CRYSTAL, R.G. (1997). Innate immune mechanisms dominate elimination of adenoviral vectors following in vivo administration. Hum. Gene Ther. 8, 37-44.

WOLD, W.S.M., and GOODING, L.R. (1991). Region E3 of adenovirus: A cassette of genes involved in host immunosurveillance and virus-cell interactions. Virology 184, 1-8.

VIEIRA, P., DE WAAL MALEFYT, R., DANG, M.N., JOHNSON, K.E., KASTELEIN, R., FIORENTINO, D.F., DE VRIES, J.E., RONCAROLO, M.G., MOSMANN, T.R., and MOORE, K.W. (1991). Isolation and expression of human cytokine synthesis inhibitory factor cDNA clones: homology to Epstein-Barr virus open reading frame BCRFI. Proc. Natl. Acad. Sci. USA 88, $1172-1176$.

YANG, Y., NUNES, F.A., BERENCSI, K., FURTH, E.E., GONCZOL, E., and WILSON, J.M. (1994a). Cellular immunity to viral antigens limits E1-deleted adenoviruses for gene therapy. Proc. Natl. Acad. Sci. USA 91, 4407-4411.

YANG, Y., HILDEGUND, C. J.E., and WILSON, J.M. (1994b). MHC class I-restricted cytotoxic $\mathrm{T}$ lymphocytes to viral antigens destroy 
hepatocytes in mice infected with E1-deleted recombinant adenoviruses. Immunity 1, 433-442.

YANG, Y., NUNES, F.A., BERENSCI, K., GONCZOL, E., ENGELHARDT, J.F., and WILSON, J.M. (1994c). Inactivation of E2a in recombinant adenoviruses improves the prospect for gene therapy in cystic fibrosis. Nature Genet. 7, 362-369.

YAO, S., FARJO, A., ROESSLER, B.J., DAVIDSON, B.L., and KURACHI, K. (1996). Adenovirus-mediated transfer of human factor IX gene in immunodeficient and normal mice: evidence for prolonged stability and activity of the transgene in liver. Viral Immunol. 9, 141-153.
Address reprint requests to: Dr. Jonathan S. Bromberg Department of Surgery University of Michigan 2926 Taubman Center Ann Arbor, MI 48109-0331

Received for publication March 6, 1997; accepted after revision May 14, 1997. 


\section{This article has been cited by:}

1. Beate Kuttler, Heike Wanka, Nora Klöting, Bernhard Gerstmayer, Hans-Dieter Volk, Birgit Sawitzki, Thomas Ritter. 2007. Ex vivo gene transfer of viral interleukin-10 to BB rat islets: no protection after transplantation to diabetic $\mathrm{BB}$ rats. Journal of Cellular and Molecular Medicine 11:4, 868-880. [CrossRef]

2. N Gong, U Pleyer, H-D Volk, T Ritter. 2007. Effects of local and systemic viral interleukin-10 gene transfer on corneal allograft survival. Gene Therapy 14:6, 484-490. [CrossRef]

3. Nianqiao Gong, Uwe Pleyer, Jun Yang, Katrin Vogt, Marcelo Hill, Ignacio Anegon, Hans-Dieter Volk, Thomas Ritter. 2006. Influence of local and systemic CTLA4Ig gene transfer on corneal allograft survival. The Journal of Gene Medicine 8:4, 459-467. [CrossRef]

4. J Zhao, G J Pettigrew, E M Bolton, C R Murfitt, A Carmichael, J A Bradley, A M L Lever. 2005. Lentivirus-mediated gene transfer of viral interleukin-10 delays but does not prevent cardiac allograft rejection. Gene Therapy 12:20, 1509-1516. [CrossRef]

5. P Gallo, S Dharmapuri, B Cipriani, P Monaci. 2005. Adenovirus as vehicle for anticancer genetic immunotherapy. Gene Therapy 12, S84-S91. [CrossRef]

6. Christine Brandt, Jun Yang, Isabella Schmitt-Knosalla, Anja Siepert, Markus H. Hammer, Katrin Vogt, Birgit Sawitzki, Manfred Lehmann, Hans-Dieter Volk, Thomas Ritter. 2005. Allo-specific T-Cells Encoding for Viral IL-10 Exert Strong Immunomodulatory Effects in vitro but Fail to Prevent Graft Rejection. American Journal of Transplantation 5:2, 268-281. [CrossRef]

7. B van Etten, A M M Eggermont, G Ambagtsheer, S T van Tiel, T L M ten Hagen. 2004. Impaired neutralising antibody formation and high transduction efficacy after isolated hepatic perfusion with adenoviral vectors. British Journal of Cancer 91:8, 1610-1613. [CrossRef]

8. Shashikumar K. Salgar , Dinghua Yang, Phillip Ruiz , Joshua Miller , Andreas G. Tzakis . 2004. Viral Interleukin-10-Engineered Autologous Hematopoietic Stem Cell Therapy: A Novel Gene Therapy Approach to Prevent Graft RejectionViral Interleukin-10-Engineered Autologous Hematopoietic Stem Cell Therapy: A Novel Gene Therapy Approach to Prevent Graft Rejection. Human Gene Therapy 15:2, 131-144. [Abstract] [PDF] [PDF Plus]

9. Dongmei Chen, Yaozhong Ding, Nan Zhang, Bernd Schroppel, Shuang Fu, Weiping Zang, Haojiang Zhang, Wayne W. Hancock, Jonathan S. Bromberg. 2004. Viral IL-10 Gene Transfer Inhibits the Expression of Multiple Chemokine and Chemokine Receptor Genes Induced by Inflammatory or Adaptive Immune Stimuli. American Journal of Transplantation 3:12, 1538-1549. [CrossRef]

10. Dongmei Chen, Yaozhong Ding, Bernd Schroppel, Nan Zhang, Shuang Fu, Dan Chen, Haojiang Zhang, Jonathan S. Bromberg. 2003. Differential Chemokine and Chemokine Receptor Gene Induction by Ischemia, Alloantigen, and Gene Transfer in Cardiac Grafts. American Journal of Transplantation 3:10, 1216-1229. [CrossRef]

11. John Belperio, Michael Keane, Robert Strieter. 2003. Current Opinion in Organ Transplantation 8:3, 228-238. [CrossRef]

12. Shuang Fu, Dongmei Chen, Xia Mao, Nan Zhang, Yaozhong Ding, Jonathan S. Bromberg. 2003. Feline Immunodeficiency Virus-Mediated Viral Interleukin-10 Gene Transfer Prolongs Non-Vascularized Cardiac Allograft Survival. American Journal of Transplantation 3:5, 552-561. [CrossRef]

13. P. Fender, L. Jeanson, M. A. Ivanov, P. Colin, J. Mallet, J. F. Dedieu, M. Latta-Mahieu. 2002. Controlled transgene expression by E1-E4-defective adenovirus vectors harbouring a ?tet-on? switch system. The Journal of Gene Medicine 4:6, 668-675. [CrossRef]

14. Usha Nagavarapu, Kenneth Relloma, G. Scott Herron. 2002. Membrane Type 1 Matrix Metalloproteinase Regulates Cellular Invasiveness and Survival in Cutaneous Epidermal Cells. Journal of Investigative Dermatology 118:4, 573-581. [CrossRef]

15. Kevin W. Moore, Rene de Waal Malefyt, Robert L. Coffman, Anne O'Garra. 2001. INTERLEUKIN-10 AND THE INTERLEUKIN-10 RECEPTOR. Annual Review of Immunology 19:1, 683-765. [CrossRef]

16. Bart De Geest, Sophie Van Linthout, Marleen Lox , Desire Collen , Paul Holvoet . 2000. Sustained Expression of Human Apolipoprotein A-I after Adenoviral Gene Transfer in C57BL/6 Mice: Role of Apolipoprotein A-I Promoter, Apolipoprotein A-I Introns, and Human Apolipoprotein E EnhancerSustained Expression of Human Apolipoprotein 
A-I after Adenoviral Gene Transfer in C57BL/6 Mice: Role of Apolipoprotein A-I Promoter, Apolipoprotein A-I Introns, and Human Apolipoprotein E Enhancer. Human Gene Therapy 11:1, 101-112. [Abstract] [PDF] [PDF Plus]

17. Sherri Y. Chan, Marisa C. Louie, Joseph R. Piccotti, Gaitry Iyer, Xu Ling, Zhi-Yong Yang, Gary J. Nabel, D. Keith Bishop. 1998. Genetic Vaccination-Induced Immune Responses to the Human Immunodeficiency Virus Protein Rev: Emergence of the Interleukin 2-Producing Helper T LymphocyteGenetic Vaccination-Induced Immune Responses to the Human Immunodeficiency Virus Protein Rev: Emergence of the Interleukin 2-Producing Helper T Lymphocyte. Human Gene Therapy 9:15, 2187-2196. [Abstract] [PDF] [PDF Plus]

18. Guadalupe Bilbao, Jesús Gómez-Navarro, Juan Luis Contreras, David T Curiel. 1998. Advances in adenoviral vectors for cancer gene therapy. Expert Opinion on Therapeutic Patents 7:12, 1427-1446. [CrossRef] 